\title{
COMPRESSION AND MODIFICATION IN THE ADAPTATION OF UNCLE TOM'S CABIN
}

\section{SIMONA TAMULI}

Department of English, Biswanath College of Agriculture, AAU, Assam, India

ABSTRACT
This paper studies movie adaptation of the Novel Uncle Tom's Cabin. It has been our purpose to show how themes change,
character are dropped and new emphasize in laid on themes that may not have been anticipated in the narrative discourse of the
novel. The novel is a story revolving Slavery. The Movie version of 1987 directed by Stan Lathan follows the text to a great
extent but makes certain changes in the end. The differences lessen the impact and intensity of Slavery as intended by the
Author. The paper also deals with the 1927 silent movie version directed by Harry A Pollard which Modifies and changes the
novel to such an extent that at one point the connection between the novel and movie is confused. The aim of this paper is to
look at two movie versions of Harriet Beecher Stowe's Uncle Tom's Cabin.
KEYWORDS: Movie, Novel, Slavery

Received: Sep 15, 2020; Accepted: Oct 05, 2020; Published: Oct 23, 2020; Paper Id.: IJELAUG202010

\section{INTRODUCTION}

Uncle Tom's Cabin is a novel that tells the story of Tom's journey to freedom and Arthur Shelby of Kentucky has to sell his most devoted servant Tom along with a young boy name Harry to a slave trader Halley. Slavery is the predominant theme in the novel. Uncle Tom's Cabin was written after the passage of the Fugitive Slave Act of 1850, which made it illegal for anyone in the United States to offer aid or assistance to a runaway slave. The novel seeks to attack this law and the institution it protected, ceaselessly advocating the immediate emancipation of the slaves and freedom for all people.

\section{UNCLE TOM'S CABIN (1987)}

Uncle Tom's Cabin has been adapted into different movies and plays. The latest movie version was released in 1987. It is directed by Stan Lathan and adapted by John Gay. Avery Brooks play the role of Tom in the movie.

\section{Beginning}

The movie begins with a person running from some people riding horses and finally he dived into a river and finally swims across the river. Then a white boy runs towers a big white house and enters a cabin. When he addresses the person inside the cabin as Tom, it makes it clear that it is Uncle Tom's Cabin. The novel on the other hand begins with two people having a conversation in a well-furnished dining hall: "Late in the afternoon of a chilly day in February, two gentlemen were sitting alone over their wine, in a well-furnished dining parlor, in the town of $P_{-}$, in Kentucky." (Chapter one, page one). This conversation takes place between Mr. Shelby, the owner of the house and Haley, the trade slaver. The movie shows Tom and Master Shelby coming out of the house to see a man in horse arriving whereas in the novel, Haley appears before Tom and Mr. Shelby. The movie probably begins with the scene in the cabin to portray the friendly environment in that place and to focus on the point that slaves are treated as family in that place.

\section{Eliza's Journey}

Eliza's escape journey in the movie is quite steady compared to the novel. The fear and anxiety in the novel shown in the 
novel is missing in the movie. Chapter Seven portrays Eliza's struggle on the frosty road. She enters the village of T-, by the Ohio River and river is described to be floating with great cakes of ice. When Haley almost catches her, she jumps into a raft of ice to cross the river: "With wild cries and desperate energy she leaped to another and still another cake;stumbling,-leaping,-slipping,-springing upward again! Her shoes are gone,-her stockings cut from her feet,-while blood marked every step; but she saw nothing, felt nothing, till dimly, as in a dream, she saw the Ohio side, and a man helping her up the bank."(Chapter seven, 92). In 15:30 of the movie, the raft shown is a normal bamboo raft and the river is not as shown as scary as depicted in the novel.

\section{Portrayal of Characters}

Aunt Chloe is portrayed in the movie as a tall and thin woman; whereas the novel describes her as a plump woman. In fact the description of Aunt Chloe doesn't match the character in the movie:

"A round, black, shining face is hers, so glossy as to suggest the idea that she might have been washed over with white of eggs, like one of her own tea rusks. Her whole plump countenance beams with satisfaction and contentment from under her well starched checked turban, bearing on it, however, if we must confess it, a little of that tinge of self-consciousness which becomes the first cook of the neighborhood, as Aunt Chloe was universally held and acknowledged to be." (Chapter four, page 31)

The movie doesn't clearly tell the viewer about Eliza's husband, George Harris. The conversation with George in chapter three encouraged Eliza to run away. The movie doesn't feature chapter two and chapter three which gives the viewers a clear idea of George Harris, his reason of running away and his wife's final destination in mind.

"To Canada," said he, straightening himself up; "and when I am there, I'll buy; that's all the hope that's left us. You have a kind master that won't refuse to sell you. I'll buy you and the boy;-God helping me, I will!'(Chapter three, 28)

Chapter eleven, which describes George situation after he runs away and the conversation between him and Mr. Wilson, is important to his journey. Since, this chapter is not featured as well; it is inevitable that the movie is not interested in focusing on George Harris.

Tom's introduction with Evangelina is briefed in the movie. The movie also doesn't show of St Clare's cousin Miss Ophelia with them on the ferry. She plays a significant role in the novel:

\footnotetext{
"His only daughter was exceedingly delicate, and he feared that, with no one to look after her and attend to her, her health and life might yet fall a sacrifice to her mother's inefficiency. He had taken her with him on a tour to Vermont, and had persuaded his cousins, Miss Ophelia St. Clare, to return with him to his southern residence; and they are now returning on this boat, where we have introduced them to our readers."'(Chapter fifteen, 240-241)
}

Before Eliza is sent to the Quaker settlement, she seeks for refuge at Mr. Birds place, however, the movie directly shows Eliza at Quaker settlement where she receives the good news of George's arrival. The movie summarizes the events as fast 
as possible because of the convenience of the screenplay. In the process the emotional attachment is lost. Neither slavery nor motherhood is intensely felt as one does while reading the novel

\section{Prioritizing One Plot over the Others}

The story in the novel focuses on two plot. The first is Eliza and George's struggle to escape to Canada and the other is the journey of Tom. However, the movie mainly focuses on Tom instead of George and Eliza. Not only George's introduction is not properly presented for the viewers, their journey is summarized as briefly as possible and therefore the viewer cannot feel much attachment with these two characters.

After Eliza swims across the river, she is depicted in a miserable condition in the novel. The movie has portrayed this condition very casually. Therefore the hardship faced by Eliza and their relation doesn't emotionally move the audience as it moves the readers. In chapter three, when George tells Eliza that he will have to go away and when they part, it creates an emotional bonding with them in the beginning itself.

"Well, now, good-by," said George, holding Eliza's hands, and gazing into her eyes, without moving. They stood silent; then there were last words, and sobs, and bitter weeping,-such parting as those may make whose hope to meet again is as the spider's web,-and the husband and wife were parted."(Chapter three, 29)

Running away is not easy for Eliza as it is shown in the movie. The white folks weren't that kind to slaves as they show in the movie. Slaves were treated as animals. But maternal love persuades Eliza to run away:

"Her husband's suffering and dangers and the danger of her child, all blended in her mind, with a confused and stunning sense of the risk she was running, in leaving the only home she had ever known, and cutting loose from the only protection of a friend whom she loved and revered." (Chapter seven, 75)

The movie doesn't make Eliza seem that worried about her husband. The only time she is shown worried about George is around 10:57 before her escape where she tells Tom that George ran away to Canada because his master beats him up.

\section{Lack of Clarity and Intrinsic Details}

Tom's life in Southern residence is also briefed. The most noteworthy thing is the movie shows the events but doesn't show the reasons leading to the event. For example, 34:38 shows St Claire bringing Topsy to Ophelia so that she can teach and parent her. However, the movie doesn't show Ophelia's problem regarding the household. Her ways are so different from the Southern ways of living that creates a rift between her and the entire domestic help.

" The first morning of her regency, Miss Ophelia was up at four o'clock; and having attended to all adjustments of her own chamber, as she had done ever since she came there, to her amazement of the chambermaid, she prepared for a vigorous onslaught on the cupboards and closets of the establishment of which she had the keys." (Chapter eighteen, 318)

Evangeline's illness is not shown severe in the movie. 47:50 of the movie shows her in bed which gives the viewers the idea that she may be ill. The novel stresses on her illness quite deep. Evangeline 
The transformation of Eva from a bright spirited girl to a weak sick girl cannot be seen in the movie because of her limited appearances in the movie. Another important aspect of Eva that is missing in the movie is her impact over Tom. She influences Tom a lot. She is an angel to him. Her attachment with the servants of the house and her compassion towards them is an inevitable part of her characteristics. Towards the end, she gifts away her golden curls to the savants and her golden curl plays an important part in Tom's life later on. But the movie ignores this aspect as well.

'Yes, I know you do! There isn't one of you that haven't always been very kind to me; and I want to give you something that, when you look at, you shall always remember me. I'm going to give all of you a curl of my hair; and, when you look at it, think that I loved you and am gone to heaven, and that I want to see you all there."(Chapter twenty six, 449)

Tom's new master Legree is again not portrayed as cruel as he is depicted in the novel. Undoubtedly, Tom is suffering in the new place. But the intensity is not severe in the movie. The viewers won't feel that amount of agony at Tom's plight which the readers would feel. When Tom refuses to flog Cassy, he is brutally beaten up. His condition is described to be a pathetic one: "The poor woman screamed with apprehension, and all rose, as by a general impulse, while they dragged him unresisting from the place." (Chapter thirty three, 553)

\section{The Ending}

The movie ends with the death of Tom with a message that the death liberated Tom's soul. The movie doesn't feature what happened to Legree and also doesn't feature the settled life of George and Eliza in Canada. So the movie doesn't end as per the novel. However, the remaining chapters could be excluded anyway as the movie primarily focused on the journey of Tom from chains to liberation. And his death ends the story

\section{UNCLE TOM'S CABIN (1927)}

Another movie version of Uncle Tom's Cabin directed be Harry A Pollard and released by Universal Pictures was the last silent film version. An interesting thing about this movie is that all of the major slave roles, with the exception of Uncle Tom himself, were portrayed by white actors.

This version of the novel takes the liberty to change the plot as per its convenience. It tries to present a conventional story about two separated lovers united at the end. And at the same time it tries to throw light into America's history such as Civil War. Unlike the 1987 release by directed by Stan Lathan, where Tom is central to movie, this movie focus on the story of Eliza and George.

\section{The Beginning}

The movie begins on a happy note. As the screenplay informs the viewers "The Kentucky home of Shelbys- an honored name in the South since Revolutionary days." (4:48). so, it is a happy household where Eliza, their servant is getting married and happiness in apparent in the scene. The novel begins with conversation between Mr. Shelby and Haley regarding selling of slaves.

"Well then, Haley, how will you trade?" said Mr. Shelby, after an uneasy interval of silence.

"Well, haven’t you a boy or gal that you could throw in with Tom?" (Chapter one, 3) 
First sixteen minutes of the movie shows the entire household celebration Eliza and George's wedding. And the movie takes the liberty to present Halley amidst the celebration. Tom is also shown to be presented in front of Halley as he arrives from some business at Cincinnati. Another detour from the original story of the novel is seen when Edward Harris, George's master arrives at the place and takes him away from the wedding. "I come to get my slave" (16:32)

Now, the conversation which begins in chapter one of the novel starts in the movie in 20:40. On the other hand, George and Eliza's escape is also shown around that scene itself. George comes to bid farewell to Eliza and as he escapes. Jim is fiddling with the door and in the process Eliza comes to know that her son is sold. In the novel, the deal is disclosed to her as she eavesdrops on Mr. and Mrs. Shelby's conversation.

"Communication with their apartment was a large closet, opening by a door into the outer passage. When Mrs. Shelby had dismissed Eliza for the night her feverish and excited mind had suggested the idea of his closet; and she had hidden herself there, and with her ear pressed close against the crack of the door, had lost not a word of the conversation." (Chapter five, 54)

The movie also shows Edward Harris arrival at the Shelby residence in the very sitting where they are dealing on Tom and Jim. "My man, George has run away- the dogs have tracked him here" (32:01)

The novel shows Sam and Andy accompanying Hally in search of Eliza and her son. The movie makes it a serious affair with hounds and Edward Harris accompanying the search party. Eliza's escape by crossing the river Ohio is made quite dramatic in the movie. The novel undoubtedly depict river Ohio in a dangerous state especially with block of ice. But the way she escapes is quite dramatic in the movie. The appearance of Phineas Fletcher, a Quaker in a free state and the way he helps Eliza to cross the river completely made up.

Tom's departure from Kentucky is shown much later at 45:35. In the steam boat, Augustine of St Care, Evangeline and Ophelia are present as per the novel. But the noteworthy thing is the presence of George Harris in the boat. Maybe due to the inconvenience of carrying on two plots at different setting, the movie decided to intertwine the story of Tom and the fate of George and Eliza along the same path. The capture of Eliza from the Quaker settlement and her appearance in the both is even more noteworthy. "Stolen by Marks and Looker- chained to the string of human freight, Eliza and Harry awaits shipment-down the river" (51:09) .In the novel, Eliza is not captured. Another twist seen the boat is the escape of George from the boat.

"I take my slaves off at the next landing. Get the boy ready." (57:46) But the way they try to get the boy away from the mother is quite comic. Luring the boy to come away from his mother turns out to be effective but the traders are not as kind as they are depicted in the scene.

The scene that follows which shows Eliza trying to save her boy from the trader is a complete addition. At the end she doesn't even manage to save her boy from the traders but the motherhood and the struggle that a mother can undergo because of her child becomes apparent in the scene. The way she embraced her son while he is in the cart (1:04:13) and then the way she beats up the man (1:04:20) moves the audience emotionally. Maybe this scene is incorporated to build an emotional bond with the audience.

\section{Usage Of Quotes, Props And Additional Scenes}

While the novel deals with the bondage and physical slavery, the movie tries to lead a way to freedom, liberty and physical 
freedom. It quotes Abraham Lincoln "A house divided against itself cannot stand. I do not believe that this Government can permanently endure half slave and half free." And then also informs the audience that Civil War has begun. It also suggest in a way that happy ending is approaching.

Tom reading newspaper in 1:07:00 is another addition in the movie. As the novel informs, Tom has difficulty in reading Bible itself.

1:08:02 again create a comic scene with Ophelia and Topsy where Topsy hides behind Ophelia and calls her. Topsy's expression and gestures makes the audiences laugh and her character is lighter than the one portrayed in the novel. In the same time, the intensity of her feeling as she talks with Eva is deep. "I ain't cryin'- it's jes' my weak eyes." (1:16:02). the goodness of Eva is portrayed with a Halo as she is consoling Topsy (1:16:49). The movie uses such technique in the next scene where they show a white angel comes to take her away $(1: 18: 16)$

The movie uses the help of newspaper to inform the audience the news of St Claire's slave's auctioning. Interestingly, the scene shows the auctioning of Eliza as well. The story of Eliza and George is completely drifted from the original story of the novel. And Simon Legree buys Eliza along with Tom "Sold to Simon Legree" (1:24:38) Lemuel Proctor is said to have Eliza's son and George is trying to find him. This is not even mentioned in the novel.

In Simon Legree's place also the movie focus more on Eliza than Tom. Tom is very brutally treated here as per the novel. The only time, Tom is shown beaten here in the movie is when he refuse to beat up Cassy (1:30:18). Legree shows his supremacy over Tom “Didn’t I pay twelve hundred dollars for you- ain’t you mine, body and soul? “ (1:30:22). 1:33:54 Tom is shown to be lying down but even if the audience assume that Tom is in pain, the scene focus on the discovery of Eliza's past. She is Cassy's daughter.

On one hand, Legree's realm and on the other hand "And the marching feet of the liberating host thundered nearer - ever- nearer" (1:31:05). The novel doesn't mention anything in such. When the novel deals with the brutality on the slaves, the movie tries to emphasize on the liberty after the brutality. "And the song they sang was a new song of bondage broken and chains forever lifted-". The slaves' owners are fleeting in terror and during such moment George finds his son and they rejoice at their liberty. The inclusion of this liberty in the movie adds a whole new dimension into the original story. The movie is not following the novel towards the end so it discloses the fact to Eliza that Cassy is her mother in Legree's house itself "Lord God Almighty, child- I'm your mother." (1:37:33)

The movie no doubt uses the novel's idea of Cassy's escape by hiding in the house and scaring Legree.

"Gradually, the staircase that led to the garret, and even the passage-way to the staircase, was avoided by everyone in the house, from every one fearing to speak of it, and the legend was gradually falling into desuetude. It had suddenly occurred to Cassy to make use of the superstitious excitability, which was so great in Legree, for the purpose of her liberation, and that of her fellow-sufferer." (Chapter thirty-nine, 618)

In the movie, while Eliza and Cassy is hiding in the garret, the liberating army is marching on the other hand (1:40:56). So, it is obvious that they are going to escape anyway. The movie also shows Eliza and Cassy's encounter at the Garret where Cassy beat s him up (1:50:24)

\section{Tom's Death}

Tom's death is utmost important to the novel. His death suggests his journey from slavery to freedom. The movie, no doubt 
shows a journey from slavery to freedom but this freedom is shown physically and that through the liberation of Eliza and George.1:54:22 shows Eliza and George together with their son and the movie projects the marching of the army in the background to show how their country has put effort to liberate the slaves.

Master George, Mr. Shelby's son doesn't come to take back Tom with him as he does in the movie. Tom's death has a deep impact on the people around him and his death is a kind of victory for him but the movie doesn't focus that.

"Don't call me poor fellow!" said Tom, solemnly. "I have been poor fellow; but that's all past and gone, now. I'm right in the door, going into glory! Oh, Mas'r George! Heaven has come! I've got the victory!- the Lord Jesus has given it to me! Glory be his name!" (Chapter forty one, 647)

"I forgive you-as I hope to be forgiven" (1:45:12) says Tom and he dies. The martyrdom and the victory that is evident in the novel is absent in the movie. Death of Tom is like death of any other slave. As the name of the movie suggests, the movie doesn't deal with it. The title doesn't justify the movie.

\section{Movie Vs Novel Conclusion}

The movie although uses the basic essence and characters of the novel, the story line is drifts to a great extent. The novel is a story of a man who is pious and a good servant who moves the shackles of chain by his compassionate nature and finally finds bliss in death. Death is depicted as a redeemer and a leveller. The novel is a story on motherhood and struggle of a couple to be united. The novel is a story of good soul like Evangeline amidst the brutality of slavery in the form of Simon Legree.

The movie is about a couple who is separated to be united at the end. The movie changes the story and brings in different twist. Tom is not altogether ignored in the movie but at point it may seem that if Tom's character is removed from the movie, it won't bring much change to the story.

The end is also different from the novel. The novel describes freedom in form of death and George and Eliza finds freedom in Canada. However, the movie portrays freedom in the form of physical liberation in America itself. Tom's death doesn't move the audience as much as the union of Eliza with her husband and son does.

The novel highlights the brutality and physical atrocities of slavery. The inhuman situation and condition of the slaves, the way they are sold, and the way they are beaten up and most importantly the way they are destined to live. The movie and novel shares one important aspect and that is George tries to change his own fate in both printed and visual version. The novel also depicts Eliza doing the same as she accompanies her husband from Quaker Settlement onward. The movie, on the other hand, puts Eliza in captive since Quaker Settlement and that brings much variation in the plots.

\section{REFERENCES}

1. Boyum, Joy Goud. Double Exposure: Fiction into Film. New York: Universe Books, 1985. Print

2. Bluestone, George. Novels into Films. Berkeley: University of California Press, 1961.Print

3. Schol, Annie Marie. Adaptation as Reception: How a Transnational Analysis of Hollywood Films Can Renew the Literatureto-Film Debates Amerikastudien/American Studies, Vol.54, No. 4(2009),pp.657-682

4. Stowe, Harriet Beecher. Uncle Tom's Cabin. New York: Alladin Classic, 2002. Print 
5. Zatlin, Phyllis. "On and Off the Screen: The Many Faces of Adaptation" Theatrical Translation and film Adaptation: A practitioner's view. U.K: Multilingual Matters Ltd, 2005 